\title{
A Study on the Higher Vocational English Teaching Reform under the Background of "Internet +"
}

\author{
Pei Zhou
}

Luohe Medical College, Luohe City, Henan Province, 462000, China

\begin{abstract}
Education informatization has become a new trend in the "Internet + " era, however, a lot of English Teaching in Higher Vocational Colleges in our country still follows the traditional teaching mode. Based on the author's teaching experience, this paper first analyzed the characteristics of English Teaching in Higher Vocational Colleges under the background of "Internet +", and then put forward the reform countermeasures of English Teaching in Higher Vocational Colleges. This paper considers that only by playing the role of online education under the background of "Internet + " can we increase the direct communication with students, provide students with a good English learning environment, and stimulate students' interest in learning English.

Key words: "Internet +"; Higher Vocational Education; English Teaching; Reform

\section{Introduction}

Since the concept of "Internet + " is put forward in 2012, the world economy has gradually entered the "Internet +" era. In 2015, Premier Li Keqiang once referred to the "Internet +" in the government work report, and developed a "Internet +" action plan, which is a new economic action under the new normal programme. As one of the works that are most closely linked with economic development, the vocational education can not be absent[1]. Internet plus vocational education is not a simple superposition, but a kind of innovation. It is not only the use of Internet tools in the teaching process, but the innovation from the thinking mode to the teaching mode. The teacher should establish the new teaching idea, and the student should raise the new learning idea.
\end{abstract}




\section{The characteristics of English Teaching in Higher Vocational Colleges under the Background of "Internet +"}

\section{1 convenient}

The popularity of smart phones, computers, tablet makes the Internet accessing more and more convenient. Students can learn what they want online. For example, through VOA, BBC slow news, CNN student English news, audio data, they can get the latest information in English. Through distance education, students can learn the corresponding knowledge. In the era of big data, there are a variety of communication platform and learning websites, so the Higher vocational college students can quickly acquire the knowledge that they are interested in by using the platform of English teaching resources or using the interactive educational platform. We can download the resources we need, and upload the original video, audio and learning materials[2].

\section{2 industrialization}

English Teaching in Higher Vocational Colleges under the background of "Internet + " focuses on practicality and communication. According to the needs of employers, combined with the school's professional, set up personnel training programs, emphasis on learning English. Create quality courses, industry textbooks, and use the network to conduct online teaching. Schools can also cooperate with each other, to create a professional English learning platform. With the economic globalization, English is becoming more and more important in all walks of life. We carry out the construction of a learning system through the Internet, for example the Koolearn English learning platform strengthening students' oral English, listening training, learning tourism, hotels, trade and other industries. Train the technical talents with high level, to improve students' oral communication ability and competitive ability.

\section{3 personalization}

The most significant feature under the background of "Internet + " is the respect for the individual, so it can meet the personalized needs of teaching, fully be aware of the differences between each individual, and make up for the shortcomings of traditional teaching. Students in different regions and levels can choose different courses. Cloud computing and data mining technology can establish the teaching resources database and record the learning trajectory, including the answer time, error point and comparative accuracy of spoken language, so the process and results of students' learning can be analyzed dynamically. The information collected by the mobile terminal and the computer terminal can be interconnected with each other, and a targeted learning scheme is 
proposed for each learner. Higher vocational English teaching based on the development of network technology can provide students with learning information, such as the oral application of students, test error rate etc., to help teacher to analyze and predict students' weak course, so we can purposefully correct learning errors, which can maximize the efficiency of teaching and save time for teachers[3].

\section{Higher Vocational English Teaching Reform under the Background of "Internet +"}

\subsection{Create a English learning environment}

For many years, the difficulty in English teaching is listening and speaking, however the English teaching under the background of "Internet + " is able to make up for this deficiency and contributes to interactive teaching. The real simulation of the hotel, tourism and other teaching environment can design an efficient English learning plan. We can use the Internet, multimedia, speech room and other audio-visual means to establish an independent learning platform. For example, the special training of spoken language. According to the theme to set the communicative scene, students can simulate the sentence pattern, dialogue, and record it down in this process, so it is easy to find the mistakes and then correct them[4]. The popularity of smart phones makes English learning more convenient. Instead of letting students indulge in video games, it's better to integrate into their world, to establish QQ, WeChat group, then we can timely communicate with students, it is a better way for homework assigning and questions answering. Students can get what they want to learn anytime, anywhere, such as audio, video, learning software, at the same time, teachers can use it for supervision and guidance.

\subsection{Open micro course education with the advantage of "Internet +"}

In view of the fact that the college entrance examination scores of college students are different, and the English foundation is relatively weak, we should use the advantage of "Internet +" to enrich the teaching content, attract students' interest in learning, change the traditional teaching mode of English teaching, open up fresh plates, create a new mode of interaction between teachers and students. With the rapid development of the Internet, the students have more abundant English learning channels, achieving a transform from the reality classroom space to online classroom, but the core of its teaching needs to be further attention. Let the micro class form for the teaching of English teaching content[5]. English Teaching in higher vocational colleges is based on the needs of the market, so it is necessary to improve students' ability and communicative competence of English. The traditional collective teaching only attaches importance to reading and writing ability, while ignoring the level of listening and speaking, so it is difficult to accomplish it only relying on traditional 
collective teaching. At the same time, the use of multimedia teaching and other teaching techniques introduced in the flexible use of "Internet + " can be integrated into the real life, and we can also design a network of reading and communication, to achieve the simultaneous improvement of listening, speaking, reading and writing.

\subsection{Improve the teaching evaluation system with the advantage of "Internet $+"$}

According to the development trend of English teaching reform in Higher Vocational College, we should do a good job on English teaching evaluation system reform and adjustment, advocate dynamic evaluation and teaching. The content of assessment is not only the ability of reading and writing, but also the level of listening and speaking ability. To increase the content of oral examination and enrich the diversity of evaluation methods, it has been proved that summative assessment can evaluate the effect of students' learning. Under the "Internet + " background, the evaluation of English Teaching in higher vocational colleges is more accurate and objective and it is no longer confined to an examination paper, instead, it uses more interactive ways and more objective evaluation. The "Internet + " can show the results of "teaching" and "learning", and after absorbing teachers and students' suggestions and evaluation through the network the evaluation, the evaluation will be more objective and true[6].

The object of education evaluation is not only students but also teachers. At the same time, the "Internet + " make the data terminal record information, convenient for teachers and students to record the results of teaching. In order to objectively evaluate the teaching effect, online teaching model can help teachers to analyze the progress of students. Therefore, it can provide the reference for the next step of the teaching design, find out the deficiencies of the students, and put forward the personality chemistry case for the students.

\subsection{Improve English teaching level with the advantage of "Internet +"}

Schools should encourage teachers to further study to get greater improvement and improve their teaching level through online learning, online education, distance education with less investment. English curriculum design under the "Internet +" should build a new learning platform, search for students interested in English teaching resources, and the teaching design should combine with the network. Teachers should be based on the status of different students teaching programs to design question bank, for example, according to the college entrance examination scores and wishes to divide the students into several grades, so that students can choose their own level of practice courses. Students with different levels of English do not use same textbooks or lectures, beside, the exam content and questions are different, as well as the grading requirements. The simple question corresponds to the students with weak English and the difficult questions are answered by good students. Internet technology helps teachers deal with problems that were previously difficult to handle. At the same time, its rich resources attract the attention of students. English Band Four has increased the 
content of news listening, so we can download VOA or $\mathrm{BBC}$ news from the Internet for students, to teach them to listen to the news news tips, let them pay attention to tone, intonation, words and pronunciation. Students can also visit the website, exam simulation, special training. When teachers teach knowledge points, it needs use a variety of tone or play some online humorous videos, movie clips, then explores the slang. Students can find information online under the guidance of teachers to complete the task dialogue and other tasks, to provide students with unprecedented classroom experience. The combination of hearing and vision can clear the vivid image of the knowledge and improve the level of teachers' curriculum design and teaching.

\section{Conclusion}

The "Internet + " integrates knowledge teaching and practical teaching based on its powerful online learning platform and information learning resources. It is expected to be a practical and feasible way to break through the bottleneck of application ability in Higher Vocational English Teaching.

\section{Reference}

[1] Liu Hongjun. The application of Internet assisted instruction in Higher Vocational English teaching. Journal of Liaoning vocational college, (03), pp.4243, 2010 .

[2] Xu Peihong. Internet plus the era of Higher Vocational English Teaching Reform. Journal of Chizhou college, (05), pp.154-156, 2016.

[3] Zhou Hong. On the reform of English Teaching in Higher Vocational Colleges. Modernization of education, (21), pp.53-54, 2016.

[4] Zhou Hua. Ecological environment construction in Higher Vocational English Teaching in "Internet + " era. Journal of Hubei Adult Education Institute, (05), pp.50-52, 2016.

[5] Zhang Xiaoli. The study of English Teaching in Higher Vocational Colleges under the Internet environment. Modern Communication, (13), pp.181-182, 2016. [6] Hu Yaqing. To explore a new mode of English Teaching in Higher Vocational Colleges Internet plus environment. The contemporary research journal, (05), pp.61-62, 2016. 